\title{
Designing Courses that Entertain Multi-Goals: Rationale and Practice
}

\section{OPEN ACCESS}

Manuscript ID:

EDU-2021-09034038

Volume: 9

Issue: 3

Month: June

Year: 2021

P-ISSN: $2320-2653$

E-ISSN: 2582-1334

Received: 10.03.2021

Accepted: 27.04.2021

Published: 01.06.2021

Citation:

Tunaboylu, Oya.

"Designing Courses that Entertain Multi-Goals:

Rationale and Practice."

Shanlax International

Journal of Education,

vol. 9, no. 3, 2021,

pp. 173-178.

DOI:

https://doi.org/10.34293/

education.v9i3.4038

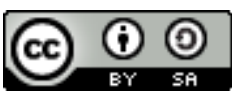

This work is licensed under a Creative Commons Attribution-ShareAlike 4.0 International License

\author{
Oya Tunaboylu \\ Associate Professor, Department of English Language Teaching \\ School of Education, Süleyman Demirel University, Isparta, Turkey \\ https://orcid.org/0000-0002-9926-7973
}

\begin{abstract}
The present century is characterized by the speed and influx of information. Given that everyday life both at home and work is flowing at head-spinning speed, the time comes fore as a crucial entity to process mountains of information produced and transmitted to the furthest places in the world with a simple click. In brief, time is a precious treasure that needs to be kept safe and spent wisely. This article reports on a study that explored the possibilities as to how teaching time and the course content could be designed more efficiently in a freshman conversation skills course offered to the prospective English language teachers at a state university in Turkey. The course content was constructed based on an initial needs analysis conducted by their searcher. As a partial requirement of the final exam, the students were asked to prepare a five-minute oral presentation on a quotation or a universal code of values of their choice. The rubric for evaluation and the outline of the oral presentation were both negotiated with the students in detail. Following their presentation, the students were asked to answer two open-ended questions eliciting their opinions about their experiences. The content analysis of the collected data revealed that the students improved research and digital literacy skills. They also established collaboration with their classmates, retained vocabulary items and overcame anxiety issues.
\end{abstract}

Keywords: EFL, Conversation skills course, Turkish teachers of English, Needs analysis, course design, Prospective teachers of English

\section{Introduction}

Speed is the mantra of today's fluid world. To keep abreast with immense flow of knowledge produced as a natural outcome of disciplinary interconnectedness and emerging new fields as a result of these happily-ever-after marriages across the disciplines, it is certainly a must to use time wisely. That is, the proliferation of knowledge needs time to learn, digest and metabolize.

In such an era, professionals from every walk of life should develop awareness toward efficient use of time and teachers are not immune from this in their work area which is the classroom. Today, teachers are expected to balance between rich content on the one hand and speed on the other. More specifically, today's language teachers are expected to design courses to help students obtain versatile and rich knowledge while entertaining multiple language learning skills. That being said, today, it is a matter of either pacing with the momentum of life or being tossed out in a discarded basket. The word 'multitasking,' from this perspective, literally captures the essence of the present era. As argued earlier, in the current century, there is much to learn but less time to do it. Therefore, time needs to be used wisely to maximize much learning.

With this in mind, the purpose of this study was to explore the possibilities to reap maximum benefits out of an undergraduate course designed for the freshman Turkish teacher candidates of English at a state university in Turkey. As a required course, conversation skills is offered in the freshman year of the English language teaching departments in Turkey. 
As a partial requirement of the final examination, the prospective teachers were asked to prepare a fiveminute prepared talk based on a quotation of their preference. The research sought answers for the following research questions?

- What are the major gains obtained from the overall experience?

- What are the students' feelings before and after the oral presentation?

\section{Related Literature}

Ever-enriching databases of today's scientific endeavors and the result abundant knowledge entail human beings to use time efficiently more than ever. For almost every profession, feeding two birds with one cone is one major goal to catch up with the motion of time and process accumulated knowledge. With this in mind, the researcher aimed at designing a conversation skills course with multiple learning goals. The course is offered as a required course in the freshman year to student English teachers for two contact hours per week. As argued earlier, knowledge is immense, but time is limited.

At the beginning of the 14-week long semester, the researcher administered an initial needs analysis to identify the needs of the students and design and evaluate the course accordingly. Needs analysis is considered a cornerstone and a prerequisite for curriculum construction processes (Sönmez 2019; Flowerdue, 2013; Özdemir, 2017). Needs analysis can be conducted for designing a course content or constructing a curriculum. In the related literature, the syllabus that is informed by the students' needs, desires and shortcomings is said to be a promising one. Within the initial needs analysis stage of the course construction, the freshman students were asked questions about what they want to improve and the kinds of activities they would love to engage. The topics they would like to talk about within the course. Initial needs analysis revealed that most students want to enrich their store of vocabulary and the second being fluency. The third need emerged to be related to pronunciation improvement.

The relevant literature on autonomy states that students learn best when they have the agency of their learning (Holec 1981; Little 1991; Dam, 2011; Benson, 2013). That is the concept of autonomy advocates the involvement of students in decisionmaking processes. Simply put, students engage in the tasks better and get involved in the learning process more when their voices are heard and incorporated into the course design. The researcher included the student teachers in designing the course.

Along with the needs analysis and autonomy, project-based language learning (PBLL) has to do with the subject of this article. PBLL has been defined by Bell (2010) as "a student-driven, teacherfacilitated approach to learning". In PBLL, both the process of learning and the end product is important. According to Stoller (2002), typically, there are several stages that need to be followed, such as; agreeing on a subject, deciding the final product (a brochure, a newspaper, chapter, etc.), the structure of the project, the ways of gathering information, analyzing the gathered information, the introduction of the final project, and evaluation of the project. Up to now, the studies conducted on the efficacy of PBLL have proved successful. That is, the studies conducted so far have revealed positive attitudes of both students and teachers toward PBLL and improved language performances as well (Pompoon 2011; Elam \& Nebit, 2012). For TBLL to be beneficial for teaching contexts, the projects, Larmer and Mergendoller (2012) argue, should have meaningful content, foster collaboration and autonomy, and yield to an end product.

The impetus for the present research was researchers' goal to maximize the learning outcomes that would be reaped out of the conversation skills course offered to freshman student teachers of English. As argued earlier, the percentage is characterized by an abundance of knowledge produced and transmitted at head-spinning speed. To respond to the momentum of the era, professionals should use time efficiently. To this end, their searcher asked the student teachers to prepare a timed talk of five minutes as a partial requirement of the final exam for the conversation skills course. The students were asked to prepare a speech on a quotation of their preference. It needs to be noted here that quotations capture the essence of the faster and tell a lot more than the number of the words they include. It would be true to say that each meaning-loaded quotation is distilled from experiential knowledge accumulated 
over the years. Thus, the quotations could serve the prospective teachers in a couple of ways; they are concise, loaded with messages to enlighten, to name only two.

Another point which needs to be mentioned is their freedom to choose the quotation. As mentioned earlier, within the framework of autonomy, students are more engaged in the tasks that they are given the right to choose; as topics like universal code of values and social responsibility we recovered in the course, the students were recommended to find out a quotation that has a universal message. The outline of the five-minute oral presentation and the evaluation rubric were both negotiated with the students. The negotiated presentation was staged as one minute devoted to the etymology/ or brief historical background of the quotation, three minutes to there as on why that quotation was chosen, examples, event, encounters, and the last one minute devoted to ending the presentation with a catchphrase/message.

\section{Materials and Methods Data Collection Tool}

A survey method was utilized to collect data. The wooden-ended questions were constructed by the researcher. The volunteer students were asked to write their opinions on their overall learning experiences. All of the students volunteered to take part in the study. Data were collected upon completion of the timed talks as a partial requirement of the final exam.

\section{Participants}

A total of 43 Turkish freshman student teachers of English participated in the study. Of the students 32 $\%$ males $(\mathrm{N}=14), 68 \%$ were females $(\mathrm{N}=29)$. Their ages range from 19 to 22 . All of the participating students received the conversation skills course as a required course for the first time.

\section{Data Analysis}

The data collected through the written statements of the students were analyzed content-wise. As there were two specific questions eliciting major benefits out of the experience and before and after feelings - what has changed? - they set two broad categories. Weber (1990) defines content analysis as a systematic approach to categorizing data based on codes. Strauss and Corbin (1998) define two different types of coding as emergent and a priori. In this study, an emergent coding system was adopted. The emerging sub-categories underneath the two broad categories were analyzed. Each paper was first numbered and was read several times. In the following section, the findings will be presented with appropriate quotations

\section{Results and Discussion}

The data for the research was collected by two open-ended questions:

\section{Question 1. What are the major gains obtained from the overall experience?}

A content analysis conducted on the responses to this question yielded to following categories. The emerging sub-categories were presented with appropriate quotations.

\section{Improved Research Skills}

Of the participating students, 11 stated that they were inclined to do some research thanks to this requirement. Some even stated that they visited the main library for the first time in a year. Some students $(\mathrm{N}=9)$ mentioned their content with the freedom of the topic. A female student stated;

“...I am not used to it. At high school, our teacher asked us to do something. In this lesson, we chose the subject that we want to talk about. I liked it. I was motivated more to prepare for my speech..." (S7)

"...I went to the main library for the first time. I felt like a college student doing research. I think we should be given more research work. I learned how to do computerized research. While researching for this exam, I have seen a lot of books in English that I can check out and read..." (S28)

The course was able to feed two birds with one cone. The requirement created an urge of library visits and researching some students.

\section{Improved Instructional Technology Literacy and Collaboration}

Although participating students can be considered 'digital natives,' in Prensky's words (2001), some students mentioned their poor technological skills. A 
female student expressed as follows;

"...I am very good at using a smartphone, but while preparing slide presentation for the exam, I noticed that I am not that good at using the computer. I asked for help. I need to learn that I will need these skills throughout my education." (S13)

Collaboration is another that is expressed by a couple of participants and is connected with technology literacy. A female student who lacked technological skills to deliver her presentation stated

"I learned to prepare slides pretty new. I was very nervous naturally. I asked one of my friends to help me during my presentation. Weal so worked together while preparing for the actual presentation..." (S14)

Another participant expressed her opinions;

"...I am very happy that I helped my friend relieve her technology anxiety before and during the oral presentation. Helping her out with laptop and slides made me feel confident..." (S11)

\section{Vocabulary Retention}

As mentioned earlier, the initial needs analysis revealed that students want to enrich their store of vocabulary. Throughout the semester, vocabulary instruction was practiced. The final oral performance evaluation rubric included an item on recycling the covered vocabulary items. In so doing, the students were encouraged to use the vocabulary items in their five-minute talk. About this, a male student stated his opinions;

“...I like learning new vocabulary, but I forget easily... once I learned that vocabulary we learned in the lessons would count to the final grade, I studied hard. I used the words in the sentences. I think I have learned at least the ones I have used ..." (S18)

\section{Awareness toward Life Matters}

As mentioned in the previous sections, the course was designed in an way that aimed at achieving multiple learning goals. That being said, one goal was to widen students' horizons by assigning them to prepare a five-minute talk on a quotation or a universal code of values of their own choice. The outline of their talk included the rationale part as to why they selected that particular quotation. This 'why' question was placed to raise awareness in the student tapping on the critical thinking skills.
The responding students mentioned their opinions in various ways. One female student who picked a quotation depicting the importance of being a good person stated her feelings;

"...I always wanted to be a different person. I mean, above average. Once I started to read about the quotation, I started to realize that what is different is not being a person above average, but being a good person...I think it is true..." (S21)

Another participant stated the following relating to the enlightenment she went through;

"...When something bad happened, I was always criticizing the others. I mean, I didn't do they did it. I found this quotation about we should first start changing ourselves. Until that time, I never owned the fault. But now, when something bad happened, I am asking myself what I could do..." (S25).

\section{Question 2: What are the students' feelings before and after the oral presentation?}

The students who responded to this question $(\mathrm{N}=12)$ stated affective feelings such as anxiety.

A female student expressing the prepared nature of the presentation

"...fortunately, we had sufficient time to prepare for this presentation. After the presentation, I am positive that I can overcome my anxiety." (S14)

Another participant expressed her feelings as follows;

"...I am a hyper son by nature and cannot feel comfortable talking to my friends. After giving this talk to my friends, I thought that it was not that scary at all. But, I think I owe it to its being a prepared talk. I don't know how many times I delivered this speech before the actual one... now I learned that preparation is helpful..." (S16).

As can be deduced from the quotations, prepared speeches are helpful with those students who need more confidence and have anxiety issues. Another student shared her feelings about the familiarity of the evaluation rubric;

"...I think it is very helpful when you sit for the exam by knowing the evaluation criteria. We discussed the criteria in the classroom. We also studied the outline of our speech in the class. It is a very useful activity for students.” (S17) 


\section{Discussion}

People say time is money. In today's hectic life, time is undeniably the most valuable asset we have. Therefore, we should try to give it its due credit. The current research attempted to explore the possibilities to maximize learning outcomes within conversation skills courses offered to prospective English language teachers. A total of 43 freshman student teachers participated in the study. The researcher designed the course content based on the results of an initial needs analysis. Vocabulary, fluency and pronunciation were stated by the participants as the skills they need improvement. A 14-week long semester was organized around these and the other topics related to the spoken English course. The participants were asked to choose a quotation, universal code of value and prepare a five-minute oral presentation as a partial requirement of the final exam assigned for the course. The researcher aimed at feeding two birds with one cone by requiring the students to give a prepared talk. The outline of the speech and the evaluation rubric were both negotiated with the students in detail. Following the oral performances, the students were asked to answer two open-ended questions about the major gains of the whole experience and comment on pre and after feelings. The findings revealed that the course design has become successful. The student-teachers stated that they improved research skills, digital literacy and collaboration.

Some students declared that this lesson and the requirement raised their awareness toward life matters and sparked enlightenment. Affective variables such as anxiety and confidence were also mentioned by the students. They stated that prepared speech relieves anxiety. The students also mentioned their content with the freedom of choosing the topic and vocabulary retention.

\section{Recommendations}

As teachers and teacher educators, we need to look for opportunities to design our courses so that our students may have maximum benefits out. Drawn from the word 'multitasking,' I argue that we need to design courses with multi-goals. Otherwise, we cannot keep up with the speed of knowledge production in the present century. In this article, the researcher shared how she designed a conversation skills course in which universal codes of values were embedded. In so doing, students raised awareness toward the universal code of values while improving language skills. In further studies, the possibilities of how we can enrich the learning outcomes of each course can be explored.

\section{Limitations}

This study was conducted by surveying a small group of subjects $(\mathrm{N}=43)$. Considering both the number of subjects who participated in the study and the data collection tool, the findings cannot be generalized beyond the context.

\section{Conflict of Interest Statement}

The author declares no conflicts of interest.

\section{References}

Bell, Stephanie. "Project-Based Learning for the 21st Century: Skills for the Future." The Clearing House, vol. 83, no. 2, 2010, pp. 39-43.

Corbin Juliet, and Anselm Strauss. Basics of Qualitative Research: Techniques and Procedures for Developing Grounded Theory. Sage Publications, 1998.

Dam, Leni. "Developing Learner Autonomy with School Kids: Principles, Practices, Results." Fostering Autonomy in Language Learning. Edited by David Gardner, 2011, pp. 40-51.

Elam , J.R., and B. Nesbit. "The Effectiveness of Project-Based Learning Utilizing Web 2.0 Tools in EFL." The JALT CALL Journal, vol. 8, no. 2, 2012, pp. 113-127.

Flowerdew, Lynne. "Needs Analysis and Curriculum Development in ESP." The Handbook of English for Specific Purposes. Edited by B. Paltridge, and Sue Starfield, John Wiley \& Sons, 2013, pp. 325-346.

Holec, Henri. Autonomy and Foreign Language Learning. Pergamon Press, 1981.

Larmer, J., and J.R. Mergendoller. 8 Essentials for RBL. 2012.

Little, David. Learner Autonomy 1: Definitions, Issues and Problems. Authentik, 1991. 
Özdemir, Neslihan Onder. "Needs Analysis." The TESOL Encyclopedia of English Language Teaching. John Wiley \& Sons, 2018.

Poonpon, Kornwipa. "Enhancing English Skills through Project-Based Learning." The English Teacher, vol. XL, 2011, pp. 1-10.

Prensky, Marc. "Digital Natives, Digital Immigrants Part 1." On the Horizon, vol. 9, no. 5, 2001, pp. 1-6.

Stoller, Fredricka L. "Project Work: A Means to Promote Language and Content."
Methodology in Language Teaching: An Anthology of Current Practice. Edited by J.C. Richards, and W.A. Renandya, Cambridge University Press, 2002, pp. 107-120.

Sönmez, Hülya. "An Examination of Needs Analysis Research in the Language Education Process." International Journal of Education \& Literacy Studies, vol. 7, no. 1, 2019, pp. 8-17.

Weber, Robert. Basic Content Analysis. Sage Publications, 1990.

\section{Author Details}

Oya Tunaboylu, Associate Professor, Department of English Language Teaching, School of Education, Süleyman Demirel University, Isparta,Turkey,Email ID: oyatunaboylu@sdu.edu.tr 